\title{
Effect of added magnesium, potassium, lime and nitrogen on oats I. Yields
}

\author{
RAILI JOKINEN \\ Agricultural Research Centre, Department of Agricultural Chemistry and Physics, \\ 01300 Vantaa 30, Finland
}

\begin{abstract}
With peat as the growth base the effect of the various combinations of three amounts of magnesium, of three of potassium, of two of lime and two of nitrogen on the grain and the straw crop yields, grown in pots, was investigated.

During three seasons the magnesium fertilization did not affect the grain or the straw yield, the weight of the grain, or the rate of maturing in the first year. After the magnesium reserve had been exhausted the annual magnesium fertilization was needed to satisfy the requirements of an abundant crop. The highest level of potassium application together with a double magnesium fertilization rate caused a slight decrease in the yield, as the amount of water soluble salts in the growth base reached a high value. A deficiency in magnesium impeded more strongly the development of the grain crop than that of the straw crop; the maturing of the crop was delayed, and the grains were small. The ratio of potassium to magnesium in the annually renewed fertilization, when both nutrients were being used, did not affect the yield of oats. The amount of nutrients used had a more important significance than the ratio of the nutrients. Increase in the amounts of potassium, lime or nitrogen each had a diminishing effect on the yield if the plants were suffering from a deficiency of magnesium. Together with magnesium these treatments increased both the grain and the straw yields. Without the magnesium fertilization the highest rate of potassium increased clearly the value of the ratio $\mathbf{K} / \mathbf{M g}$ in the growth base, and caused a decrease in the yield.
\end{abstract}

\section{Introduction}

In investigations concerned with the uptake of nutrients by plants, solutionculture is often used. The concentration of the nutrient solution flowing into the growth base and the ratios between the nutrients can thus be maintained at a constant level for the duration of the test. The uptake of nutrients by the plants is in a test affected only by the properties of the nutrients. When undecomposed peat (Sphagnum) is used as the growth base, the results are almost comparable with solution cultivation (PUUSTJÄRvi 1971). This kind of peat contains very little nutrients, however, it binds a lot of them and releases them again easily to be used up by the plants (PUUSTJ Ärvi 1968).

In the literature there is little information about the effect of various nutrients on the development of grain and straw crops of cereals when cultivated 
in solution. In the experiments the crop of the test plant has often been harvested already at the vegetative stage. In pot experiments on various growth bases magnesium fertilization has either increased significantly the grain yield of cereals (JERLSTRöm 1975), or it has had no effect (SoRTEBERg 1974). As far as the straw yields are concerned the results also vary. The yields of plants fertilized by magnesium and harvested at the vegetative stage depended among other factors on the amounts of potassium, calcium, and nitrogen (FALADE 1973, Hansen 1972). The ratios between the nutrients, on the other hand, have seldom affected the yield (OMar and El Kobbia 1966, McLean and CARBonell 1972).

In this investigation an attempt was made to clarify the effects of potassium and nitrogen fertilization, and of liming, on the grain and straw yields of oats, on the maturing, and on the grain weight when using magnesium fertilization.

\section{Material and methods}

The test was performed outdoors in the years 1970-1972 in Mitscherlichpots (5 1). Undecomposed peat (Sphagnum, $250 \mathrm{~g} / \mathrm{pot}$, Table 1) served as the growth base, because it was desirable to keep the effects of the growth base on the nutrient uptake of oats to a minimum. In the factorial experiment there were three rates of magnesium application $\left(\mathrm{Mg}_{0}=0, \mathrm{Mg}_{1}=200\right.$ and $\mathrm{Mg}_{2}=400 \mathrm{mg} /$ pot $\left.\mathrm{Mg}\right)$, three of potassium $\left(\mathrm{K}_{1}=415, \mathrm{~K}_{2}=830\right.$ and $\mathrm{K}_{4}=$ $1660 \mathrm{mg} /$ pot $\mathrm{K})$, two of lime $\left(\mathrm{Ca}_{1}=2400\right.$ and $\mathrm{Ca}_{3}=7200 \mathrm{mg} /$ pot $\left.\mathrm{Ca}\right)$ and two of nitrogen $\left(\mathrm{N}_{1}=1000\right.$ and $\mathrm{N}_{2}=2000 \mathrm{mg} /$ pot $\left.\mathrm{N}\right)$. The fertilizations were carried out with all the combinations, and the test was repeated twise. All the nutrients were supplied as pure chemicals, $\mathrm{MgSO}_{4} \cdot 7 \mathrm{H}_{2} \mathrm{O}, \mathrm{K}_{2} \mathrm{SO}_{4}$, $\mathrm{CaCO}_{3}, \mathrm{NH}_{4} \mathrm{NO}_{3}$. In addition, each pot was supplied with $436 \mathrm{mg} \mathrm{P}$ as $\mathrm{Ca}\left(\mathrm{H}_{2} \mathrm{PO}_{4}\right)_{2} \cdot \mathrm{H}_{2} \mathrm{O}, 1.8 \mathrm{mg} \mathrm{B}$ as $\mathrm{H}_{3} \mathrm{BO}_{3}, 13 \mathrm{mg} \mathrm{Cu}$ as $\mathrm{CuSO}_{4} \cdot 5 \mathrm{H}_{2} \mathrm{O}, 10 \mathrm{mg} \mathrm{Mn}$ as $\mathrm{MnSO}_{4} \cdot 7 \mathrm{H}_{2} \mathrm{O}, 11 \mathrm{mg} \mathrm{Zn}$ as $\mathrm{ZnSO}_{4} \cdot 7 \mathrm{H}_{2} \mathrm{O}$ and $4 \mathrm{mg}$ Mo as $\mathrm{Na}_{2} \mathrm{MoO}_{4}$. $2 \mathrm{H}_{2} \mathrm{O}$. The calcium carbonate was given only in the first year, and the fertilizations annually.

Into each pot 25 oat (Pendek) seeds were planted. The crop was harvested when mature. Immediately after the cutting, the dry matter content (\%)

Table 1. The properties of peat (Sphagnum).

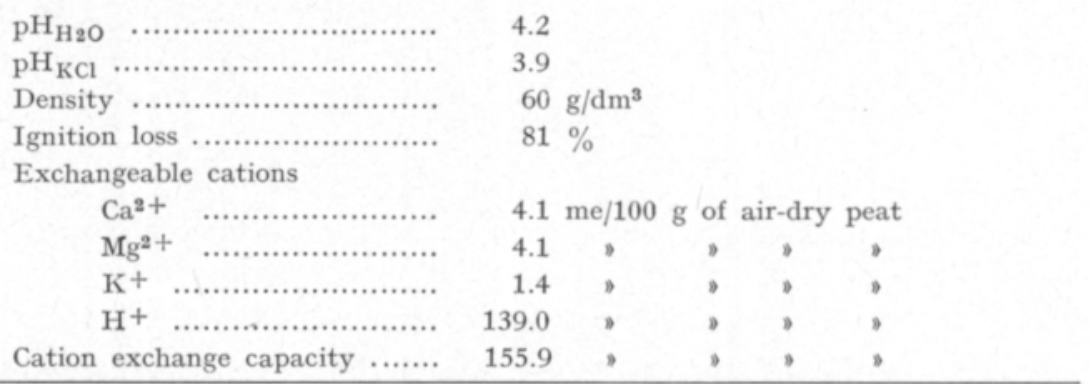


of the whole crop (grains + straws) was determined by keeping it overnight in $60^{\circ} \mathrm{C}$, and then $2 \mathrm{~h}$ in $105^{\circ} \mathrm{C}$. The weight of the oat grain was determined on the basis of four 100-grain samples. The proportion (\%) of grains in the whole yield was calculated from the dry matter yields.

The experiment continued over three seasons. The part of the experiment in which the higher rate of nitrogen was supplied was discontinued after the second year, because a further growth of the grain crop was beginning to dwindle in the pots lacking magnesium.

The exchangeable cations of peat were extracted in $1 \mathrm{~N}$ neutral ammonium acetate $(1: 60 \mathrm{w} / \mathrm{v})$. The magnesium, potassium, and calcium contents of the extract were determined by means of atomic absorption spectrophotometry, and the exchangeable hydrogen by titrating the $\mathrm{pH}$ of the extract back to seven, using $0.1 \mathrm{~N}$ sodium hydroxide solution.

The annual data results were tested by means of variance analysis, and the differences between averages by means of Duncan's new multiple range test (STEEl and Torrie 1960). The interdependencies between the nutrients and the yields were also studied by means of correlation analysis.

\section{Results}

\section{Nutrient deficiency symptoms in plants}

In the oat shoots mild symptoms of magnesium deficiency were observed already in the first year in growths that had not received magnesium fertilization. In the following years the deficiency symptoms were very strong in the plants that had received the highest potassium rate. Tripling the liming lessened the deficiency symptoms with the low level of nitrogen application, but made them more pronounced with the high level of nitrogen application in the second year. In the plants that had received the lower rate of potassium there were potassium deficiency symptoms every year.

\section{Grain and straw yields}

The magnesium treatments did not have a positive effect on the grain and the straw yields in $\mathrm{th}$ e first year (Table 2). In the pots that had received little lime the grain yield actually decreased with a magnesium sulphate fertilization, when the plants had received an abundant nitrogen and potassium fertilization. Tripling the rate of liming evened out the differences in the grain yields with various rates of magnesium.

The increase in the potassium fertilization from $K_{1}$ to $K_{2}$ increased significantly both the grain and the straw yields, regardless of the rates of lime and nitrogen. The highest rate of potassium still increased the yields when using abundant nitrogen fertilization and liming. Tripling the rate of liming had a positive effect on the grain and on the straw yields at all the levels of magnesium application, when abundant nitrogen and potassium fertilization had been used.

I n $\mathrm{t}$ he $\mathrm{s}$ e c o n d y e a r without magnesium fertilization the magnesium reserves of the growth base began to be exhausted, especially in the pots that 
Table 2. Grain and straw yields of oats (g/pot dry matter) in different years.

\begin{tabular}{ccccccccc}
\hline & \multicolumn{3}{c}{} & & & \multicolumn{3}{c}{$\mathrm{Ca}_{3}$} \\
\cline { 2 - 3 } \cline { 5 - 8 } & $\mathrm{K}_{1}$ & $\mathrm{~K}_{3}$ & $\mathrm{~K}_{4}$ & & $\mathrm{~K}_{1}$ & $\mathrm{~K}_{2}$ & $\mathrm{~K}_{4}$ \\
\hline
\end{tabular}

Grains

1 st year

\begin{tabular}{|c|c|c|c|c|c|c|}
\hline $\mathrm{N}_{1} \mathrm{Mg}_{0}$ & $40.4^{\mathrm{ab}}$ & $49.9^{\text {ede }}$ & $55.5^{\text {efghi }}$ & $43.4^{\mathrm{de}}$ & 55.7 efghi & $61.3 \mathrm{ghi}$ \\
\hline $\mathbf{M g}_{1}$ & $39.9^{\mathrm{ab}}$ & $53.0^{\mathrm{efg}}$ & 50.9 edef & $43.6^{\mathrm{bed}}$ & $53.5^{\mathrm{efgh}}$ & $59.9^{\mathrm{fgh}}$ \\
\hline $\mathrm{Mg}_{2}$ & $40.3^{\mathrm{ab}}$ & $50.2^{\mathrm{ede}}$ & $51.7 \mathrm{edef}$ & $42.6^{\mathrm{bc}}$ & $52.8^{\text {defg }}$ & $62.3^{\text {hif }}$ \\
\hline $\mathrm{N}_{2} \mathrm{Mg}_{0}$ & $39.6^{\mathrm{ab}}$ & $64.0^{1 \mathrm{jk}}$ & $68.2^{\mathrm{jk1}}$ & $32.0^{\mathrm{a}}$ & $57.2^{\text {efghi }}$ & $72.5^{\mathrm{kl}}$ \\
\hline $\mathrm{Mg}_{1}$ & $38.5^{\mathrm{ab}}$ & $59.6^{\text {fghis }}$ & $64.3^{1 \mathrm{jk}}$ & $33.3^{\mathrm{a}}$ & $57.8^{\text {efghi }}$ & $75.5^{1}$ \\
\hline $\mathrm{Mg}_{2}$ & $40.1^{\mathrm{ab}}$ & $56.2^{\mathrm{efghi}}$ & $59.0^{\text {efghl }}$ & $31.9^{\mathrm{a}}$ & $59.0^{\text {efgh } 1}$ & $76.2^{1}$ \\
\hline
\end{tabular}

2nd year

\begin{tabular}{|c|c|c|c|c|c|c|}
\hline $\mathrm{N}_{1} \mathrm{Mg}_{0}$ & $22.5^{\mathrm{c}}$ & $29.0^{\text {def }}$ & $27.1^{\text {ede }}$ & $23.7^{\mathrm{ed}}$ & $34.2^{\mathrm{fgh}}$ & $39.4^{\text {his }}$ \\
\hline $\mathrm{Mg}_{1}$ & $28.8^{\text {def }}$ & $35.7 \mathrm{gh}$ & $36.8 \mathrm{ghi}$ & 31.7 efg & $39.1^{\text {hij }}$ & $41.3^{11}$ \\
\hline $\mathrm{Mg}_{2}$ & $32.4^{\mathrm{fg}}$ & $35.1^{\mathrm{fgh}}$ & $34.4^{\mathrm{fgh}}$ & $33.6^{\mathrm{fgh}}$ & $39.4^{\text {his }}$ & $43.7 \mathrm{jk}$ \\
\hline $\mathrm{N}_{2} \mathrm{Mg}_{0}$ & $14.4^{\mathrm{b}}$ & $5.8^{\mathrm{a}}$ & $0.2^{\mathrm{a}}$ & $5.1^{\mathrm{a}}$ & $1.1^{\mathrm{a}}$ & $0.5^{\mathrm{a}}$ \\
\hline $\mathrm{Mg}_{1}$ & $30.2^{\mathrm{efg}}$ & $52.9^{1 m}$ & $50.2^{1}$ & $30.5^{\mathrm{efg}}$ & $48.7 \mathrm{kl}$ & $61.0^{\mathrm{n}}$ \\
\hline $\mathrm{Mg}_{2}$ & $30.1^{\text {ef }}$ & $46.9^{k 1}$ & $44.6^{\mathrm{Jk}}$ & $30.6^{\mathrm{efg}}$ & $44.5^{j k}$ & $56.9 \mathrm{mn}$ \\
\hline
\end{tabular}

3rd year

$\begin{array}{rrrrrrr}\mathrm{N}_{1} \mathrm{Mg}_{0} & 3.4^{\mathrm{a}} & 2.4^{\mathrm{a}} & 0.5^{\mathrm{a}} & 0.3^{\mathrm{a}} & 0.1^{\mathrm{a}} & - \\ \mathrm{Mg}_{1} & 17.4^{\mathrm{c}} & 20.1^{\mathrm{c}} & 9.1^{\mathrm{b}} & 18.9^{\mathrm{e}} & 28.4^{\mathrm{d}} & 28.7^{\mathrm{d}} \\ \mathrm{Mg}_{2} & 19.3^{\mathrm{e}} & 17.7^{\mathrm{c}} & 6.4^{\mathrm{a}} & 21.4^{\mathrm{c}} & 28.4^{\mathrm{d}} & 31.0^{\mathrm{d}}\end{array}$

Straws

1st year

$\mathrm{N}_{1} \mathrm{Mg}_{0}$

$34.6^{\mathrm{a}}$

41. $2^{\mathrm{abed}}$

45. $1^{\text {bedefg }}$

43.4abed

$54.5^{\text {hid }}$

$55.7^{1 \mathrm{jk}}$

$\mathrm{Mg}_{1}$

$36.3^{\mathrm{ab}}$

$44.2^{\text {bedef }}$

47.2 edefghi

53.5 his

55. $3^{\text {hijk }}$

$\mathrm{Mg}_{\mathbf{2}}$

$39.3^{\mathrm{abe}}$

43. $6^{\text {bede }}$

46.7 edefgh

$52.3^{\text {efghis }}$

$56.3^{j \mathrm{k}}$

$\mathrm{N}_{2} \mathrm{Mg}_{0}$

$38.0^{\mathrm{ab}}$

49.7defghis

42.6abed

52.6 fghij

$638^{\mathrm{kl}}$

$\mathrm{Mg}_{1}$

$37.3^{\mathrm{ab}}$

$55.0^{\text {hij }}$

46.6 edefgh

$48.3^{\text {defghij }}$

$55.3^{\text {hijk }}$

$64.0^{k 1}$

52.6 $6^{\text {tghij }}$

$46.6^{\text {edefgh }}$

$56.6^{\mathrm{jk}}$

$69.4^{1}$

2nd year

\begin{tabular}{|c|c|c|c|c|c|c|}
\hline $\mathrm{N}_{1} \mathrm{Mg}_{0}$ & $23.8^{\mathrm{a}}$ & $33.9^{\text {bede }}$ & $35.0^{\text {cde }}$ & $30.7^{b c}$ & $41.7^{\mathrm{efg}}$ & $46.1 \mathrm{gh}$ \\
\hline $\mathrm{Mg}_{1}$ & $30.5^{\mathrm{be}}$ & $38.6^{\mathrm{e}}$ & $40.0^{\mathrm{et}}$ & $36.7^{d}$ & $46.8 \mathrm{gh}$ & $50.2^{\mathrm{h} 1}$ \\
\hline $\mathrm{Mg}_{2}$ & $32.7^{\text {bed }}$ & $37.2^{\mathrm{d}}$ & $38.5^{e}$ & $39.1^{e}$ & $45.5^{\mathrm{fgh}}$ & $49.3^{\mathrm{ht}}$ \\
\hline $\mathrm{N}_{2} \mathrm{Mg}_{0}$ & $28.9 \mathrm{ab}$ & $25.2^{\mathrm{a}}$ & $21.9^{\mathrm{a}}$ & $29.3^{\text {be }}$ & $22.2^{\mathrm{a}}$ & $21.4^{\mathrm{a}}$ \\
\hline $\mathrm{Mg}_{1}$ & 34.9 ede & $53.4^{1 \mathrm{j}}$ & $54.0^{\text {ij }}$ & $44.8^{\mathrm{fgh}}$ & $60.2^{\mathrm{k}}$ & $71.1^{1}$ \\
\hline $\mathrm{Mg}_{2}$ & $38.1^{\text {de }}$ & $52.3^{1}$ & $46.3 \mathrm{gh}$ & $43.4^{\mathrm{efg}}$ & $58.2^{\jmath \mathrm{k}}$ & $67.0^{1}$ \\
\hline $3 r d y$ & & & & & & \\
\hline $\mathrm{N}_{1} \mathrm{Mg}_{0}$ & $14.0^{\mathrm{b}}$ & $14.6^{b}$ & $5.7^{\mathrm{a}}$ & $13.7^{\mathrm{b}}$ & $6.1^{\mathrm{a}}$ & $2.9^{\mathrm{a}}$ \\
\hline $\mathrm{Mg}_{1}$ & $24.7^{d}$ & $29.0^{\mathrm{e}}$ & $20.2^{\mathrm{e}}$ & $27.7^{\text {def }}$ & $36.9 \mathrm{gh}$ & $43.4^{1}$ \\
\hline $\mathrm{Mg}_{2}$ & $25.1^{d}$ & $27.3^{\text {de }}$ & $27.3^{\text {de }}$ & $30.7^{t}$ & $35.4 \mathrm{~g}$ & $39.1^{\mathrm{h}}$ \\
\hline
\end{tabular}

The results of the same year do not differ statistically significantly, if the same index letter appears. 
had received abundant nitrogen fertilization. In that situation a magnesium fertilization increased significantly the yieids with any of the potassium and lime rates. With a high rate of magnesium smaller yields were obtained in some cases than with a low rate of magnesium. The difference was significant, however, in both the grain and the straw yields only in pots that had received slight liming and abundant potassium fertilization. With the low rate of nitrogen the magnesium fertilization increased the yield if the plants were receiving little potassium.

Doubling the nitrogen fertilization decreased significantly the grain yield obtained without magnesium fertilization. Increasing the rate of potassium and tripling the liming strengthened the negative effect of an abundant nitrogen fertilization. The corresponding changes in the straw yields occurred in the same direction, but not to as great an extent as the changes in the grain yields.

Irrespective of the levels of lime and magnesium fertilizer application, greater grain and straw yields were obtained with the greatest potassium rate than with the smallest potassium rate when the low level of nitrogen fertilization had been used. In the pots that had received the abundant nitrogen fertilization and liming, increasing the rate of potassium has a significant positive effect on the yields when using magnesium fertilızation. In the slightly limed pots the highest rate of potassium produced smaller grain and straw yields than the medium potassium rate. The difference was significant with the high rate of magnesium application.

In the $\mathrm{th}$ i $\mathrm{rd}$ year the experiment continued with the low rate of nitrogen. The yields were smaller than in the first two years. Without a magnesium fertilization the grain yields were small or the grains did not develop at all. A magnesium fertilization caused a significant increase in the grain and the straw yields with all the rates of potassium and lime application. The two rates of magnesium application showed no differences in this respect.

With the greatest potassium rate smaller yields were obtained than with the two smaller potassium rates at all the levels of magnesium, when the peat had been slightly limed. A astrong liming removed the harmful effect of the high level of potassium, and an increase in the rate of potassium increased the straw yields significantly with both magnesium fertilizations. As far as the grain yields are concerned, an increase in the rate of potassium from $\mathrm{K}_{1}$ to $\mathrm{K}_{2}$ caused a significant increase in the yield.

The positive effect of tripling the amount of liming was significant on the grain and straw yields of oats at the two highest potassium levels when the plants were receiving a magnesium fertilization.

The greatest grain and straw yields in this pot experiment were produced by using abundant potassium and nitrogen fertilization together with strong liming and magnesium fertilization. The significance of the two rates of magnesium varied from year to year.

During the three years the magnesium fertilization increased the grain and the straw yields annually on the average as follows: 


\begin{tabular}{|c|c|c|c|c|c|c|}
\hline & \multicolumn{2}{|c|}{$\begin{array}{l}\text { Increase in yield } \\
\mathrm{g} / \text { pot }\end{array}$} & \multicolumn{2}{|c|}{$\begin{array}{c}\text { Change in yield } \\
\%\end{array}$} \\
\hline & & & $\mathrm{Mg}_{1}-\mathrm{Mg}_{0}$ & $\mathrm{Mg}_{2}-\mathrm{Mg}_{0}$ & $\mathrm{Mg}_{1}-\mathrm{Mg}_{0}$ & $\mathrm{Mg}_{2}-\mathrm{Mg}_{0}$ \\
\hline \multirow[t]{3}{*}{ Grains } & 1st year & (n........................ & -0.8 & -1.5 & 2 & 3 \\
\hline & 2nd year & (.......................... & 23.8 & 22.4 & 141 & 133 \\
\hline & 3rd year & …......................... & 19.3 & 19.6 & 1442 & 1461 \\
\hline \multirow[t]{3}{*}{ Straws } & 1st year & 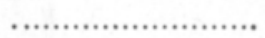 & 1.1 & 1.5 & 2 & 3 \\
\hline & 2nd year & (........................... & 16.7 & 15.1 & 56 & 50 \\
\hline & 3rd year & 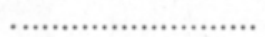 & 20.8 & 19.3 & 219 & 203 \\
\hline
\end{tabular}

In the second year the magnesium fertilization appeared to be increasing the grain and the straw yields in a more pronounced way. The difference was not, however, significant. In all the data from three years the increase in the yield due to the magnesium fertilization was the bigger the smaller the yield that was obtained without any magnesium fertilization (grains $\mathrm{r}=$ $-0.799 * * *$, straws $\mathrm{r}=-0.701 * * *)$.

The ratios between the equivalents of the annually supplied two amounts of magnesium $(200 \mathrm{mg}=16.5 \mathrm{me}$ and $400 \mathrm{mg}=32.9 \mathrm{me})$ and three amounts of potassium $(415 \mathrm{mg}=10.6 \mathrm{me}, 830 \mathrm{mg}=21.3 \mathrm{me}$ and $1660 \mathrm{mg}=42.5$ me) were $0.32,0.65,1.29$ and 2.58 . Using the fertilizers in the various ratios the following average grain and straw yields were obtained during the three years:

$\mathrm{K} / \mathrm{Mg}$ in the fertilization

$\begin{array}{cccccc}\mathrm{K}_{1} / \mathrm{Mg}_{2} & \mathrm{~K}_{1} / \mathrm{Mg}_{1} & \mathrm{~K}_{2} / \mathrm{Mg}_{2} & \mathrm{~K}_{2} / \mathrm{Mg}_{1} & \mathrm{~K}_{4} / \mathrm{Mg}_{2} & \mathrm{~K}_{4} / \mathrm{Mg}_{1} \\ 0.32 & 0.65 & 0.65 & 1.29 & 1.29 & 2.58\end{array}$

Yield g/pot

$\begin{array}{lllllll}\text { Grains } & 32.2^{\mathrm{a}} & 31.3^{\mathrm{a}} & 43.0^{\mathrm{b}} & 44.9^{\mathrm{b}} & 46.6^{\mathrm{b}} & 47.8^{\mathrm{b}} \\ \text { Straws } & 38.0^{\mathrm{a}} & 36.8^{\mathrm{a}} & 45.8^{\mathrm{b}} & 46.5^{\mathrm{b}} & 47.7^{\mathrm{b}} & 50.0^{\mathrm{b}}\end{array}$

The peat used as the growth base contained little exchangeable magnesium and potassium and an increase in the ratio $\mathrm{K} / \mathrm{Mg}$ in the fertilizer caused increases in the yields. The grain and the straw yields obtained with the ratios at 1.29 and 2.58 were significantly higher than the yields obtained with ratio at 0.32 . At $\mathrm{K} / \mathrm{Mg}$ equal to 0.65 the yield increased upon increasing the amount of either nutrient. With the ratio at 1.29 or 2.58 , increases in the amounts of nutrients, and the ratios between the nutrients, no longer atfected the yields.

\section{Grain yield as a fraction of the total yield}

The percentage figure that gives the grain yield as a lot of the whole yield describes the effect of various nutrients on the development of the grain and the straw yields (Table 3). In the beginning of the experiment the magnesium treatments did not change the grain fraction in the over-all yields. Tripling the amount of liming decreased the grain fraction at the $\mathrm{K}_{1}$ and $\mathrm{K}_{2}$ levels regardless of the rates of nitrogen and magnesium fertilization. 
In the second year with the abundant level of nitrogen fertilizer supply the deficiency in magnesium lowered the grain fraction in the whoie yield with respect to crops that had received a magnesium fertilization. The effect of other nutrients that were studied waslight. The third year results with respect to the magnesium treatments were similar to the previous ones. In addition, the highest potassium rate, even together with the magnesium, lowered the grain fraction when the rate of liming was low. As the growth in the grain yield, caused by magnesium fertilization, increased, also the grain fraction in the whole yield increased. $\left(\mathrm{r}=0.769^{* * *}, \mathrm{n}=60\right)$.

\section{Weight of the grain}

Tripling the liming rate, or doubling the nitrogen fertilization rate, depressed the weight of the oat grain in the first year at the level of the lowest potassium rate (Table 4). Increasing the rate of potassium increased the weight of the grain irrespective of the magnesium treatments.

In the second year an increase in potassium without magnesium further increased the weight of the grain in the crops that had received the low rate of nitrogen fertilizatoin. The same was found to apply in yields at the high level of nitrogen application with magnesium fertlization. Grains obtained without magnesium were smaller than others.

Between the increase, caused by the magnesium fertilization in the grain yield, and the change in the weight of the grain there prevailed a constant, positive correlation ( $\left.\mathrm{r}=0.863^{* * *}, \mathrm{n}=60\right)$.

\section{Dry matter content of the crop}

The crop was cut when the oats had matured in the majority of the pots. The dry matter content of the whole crop, determined immediately after the cutting, varied in the first year in the range $46-85 \%$, in the second year in the range $16-76 \%$, and in the third year in the range $19-52 \%$.

The dry matter content of the crops obtained in the second year with the high nitrogen fertilization rate without magnesium was $16-43 \%$, and the dry matter content of the corresponding crops, but with magnesium fertilization, was $26-41$ percent units higher. Still in the third year, the increase in the dry matter content due to the magnesium fertilization was $8-22$ percent units. The amount of green adventitious shoots in crops with a low dry matter content was high.

An increase in the potassium level from $K_{1}$ to $K_{4}$ depressed in all the years, at all the magnesium fertilization levels, the dry matter content of the crop significantly regardless of the amounts of nitrogen fertilization and liming.

\section{Nutrient contents of the growth base}

The nutrient contents of the growth base were determined from samples taken at the end of the growth season in the second year from the part of the experiment that had received the high nitrogen rate $\left(\mathrm{N}_{2}\right.$, Table 5$)$, and in the third year from the part that had received the low nitrogen rate $\left(\mathrm{N}_{1}\right.$, Table 
Table 3. Grain yield as a fraction of the total yield (\%).

\begin{tabular}{|c|c|c|c|c|c|c|}
\hline & \multicolumn{3}{|c|}{$\mathrm{Ca}_{1}$} & \multicolumn{3}{|c|}{$\mathrm{Ca}_{3}$} \\
\hline & $\mathrm{K}_{1}$ & $\mathrm{~K}_{2}$ & $\mathrm{~K}_{4}$ & $\mathrm{~K}_{1}$ & $\mathrm{~K}_{2}$ & $\mathrm{~K}_{4}$ \\
\hline \multicolumn{7}{|l|}{1 st year } \\
\hline $\mathrm{N}_{1} \mathrm{Mg}_{0}$ & $54^{\text {defg }}$ & $55^{\mathrm{efg}}$ & $55^{\mathrm{efg}}$ & $50^{\mathrm{bc}}$ & $51^{\text {bed }}$ & 53 ede \\
\hline $\mathrm{Mg}_{1}$ & 52 ede & $55^{\mathrm{efg}}$ & 52 ede & $48^{b}$ & $50^{\mathrm{be}}$ & 52 ede \\
\hline $\mathrm{Mg}_{2}$ & $51^{\text {bed }}$ & $53^{\text {edet }}$ & $54^{\text {defg }}$ & $48^{b}$ & $51^{\text {bed }}$ & $53^{\text {edef }}$ \\
\hline $\mathrm{N}_{2} \mathrm{Mg}_{0}$ & $51^{\text {bed }}$ & $57 \mathrm{~g}$ & $55^{\mathrm{efg}}$ & $43^{a}$ & $52^{\text {ede }}$ & $54^{\text {defg }}$ \\
\hline $\mathrm{Mg}_{1}$ & $51^{\text {bed }}$ & $56^{\mathrm{e}}$ & $54^{\text {defg }}$ & $41^{\mathrm{a}}$ & $51^{\text {bed }}$ & $54^{d e f g}$ \\
\hline $\mathrm{Mg}_{2}$ & $51^{\text {bed }}$ & $54^{\text {det }}$ & $53^{\text {edef }}$ & $41^{\mathrm{a}}$ & $51^{\text {bed }}$ & 52 ede \\
\hline \multicolumn{7}{|l|}{$2 n d$ year } \\
\hline $\mathrm{N}_{1} \mathrm{Mg}_{0}$ & $49 \mathrm{gh}$ & $46^{\text {defgh }}$ & $44^{\text {defg }}$ & $43^{\text {def }}$ & $45^{\text {defgh }}$ & $46^{\text {defgh }}$ \\
\hline $\mathrm{Mg}_{1}$ & $49 \mathrm{gh}$ & $48^{\text {fgh }}$ & $48^{\text {fgh }}$ & 47 efgh & $46^{\text {defgh }}$ & $45^{\text {defgh }}$ \\
\hline $\mathrm{Mg}_{2}$ & $50^{\mathrm{h}}$ & $49 \mathrm{gh}$ & $48^{\mathrm{fgh}}$ & $47^{\mathrm{efgh}}$ & $47^{\mathrm{efgh}}$ & $47^{\text {efgh }}$ \\
\hline $\mathrm{N}_{2} \mathrm{Mg}_{0}$ & $33^{e}$ & $19^{b}$ & $1^{\mathrm{a}}$ & $15^{b}$ & $5^{\mathrm{a}}$ & $2^{\mathrm{a}}$ \\
\hline $\mathrm{Mg}_{1}$ & $47 \mathrm{efgh}$ & $50^{\mathrm{h}}$ & $48^{\mathrm{tgh}}$ & $41^{\text {de }}$ & $45^{\text {defgh }}$ & $46^{\text {defgh }}$ \\
\hline $\mathrm{Mg}_{2}$ & $44^{\text {defg }}$ & 47 efgh & $49 \mathrm{gh}$ & $42^{\text {de }}$ & $44^{\text {defg }}$ & $47^{\mathrm{efgh}}$ \\
\hline \multicolumn{7}{|l|}{$3 r d$ year } \\
\hline $\mathrm{N}_{1} \mathrm{Mg}_{0}$ & $19^{b}$ & $14^{b}$ & $3^{a}$ & $2^{a}$ & $1^{\mathrm{a}}$ & 0 \\
\hline $\mathrm{Mg}_{1}$ & $40^{\mathrm{cd}}$ & $41^{\mathrm{ed}}$ & $31^{\mathrm{e}}$ & $41^{\mathrm{cd}}$ & $44^{d}$ & $40^{\mathrm{cd}}$ \\
\hline $\mathrm{Mg}_{2}$ & $44^{d}$ & $39 \mathrm{ed}$ & $30^{\mathrm{c}}$ & $41^{\mathrm{ed}}$ & $45^{d}$ & $45^{d}$ \\
\hline
\end{tabular}

Meaning of index letters same as in Table 2.

Table 4. Weight of the oat grain (mg).

\begin{tabular}{|c|c|c|c|c|c|c|}
\hline & \multicolumn{3}{|c|}{$\mathrm{Ca}_{1}$} & \multicolumn{3}{|c|}{$\mathrm{Ca}_{3}$} \\
\hline & $\mathrm{K}_{1}$ & $\mathrm{~K}_{2}$ & $\mathrm{~K}_{4}$ & $\mathrm{~K}_{1}$ & $\mathrm{~K}_{2}$ & $\mathrm{~K}_{4}$ \\
\hline \multicolumn{7}{|l|}{1 st year } \\
\hline $\mathrm{N}_{1} \mathrm{Mg}_{0}$ & $21^{\text {de }}$ & $26^{i j}$ & 291 & $22^{e f}$ & $23^{\mathrm{fg}}$ & $25^{\mathrm{hi}}$ \\
\hline $\mathrm{Mg}_{1}$ & $22^{\mathrm{et}}$ & $24 \mathrm{gh}$ & $28^{\mathrm{k} 1}$ & $21^{\text {de }}$ & $23^{\operatorname{tg}}$ & $24 \mathrm{gh}$ \\
\hline $\mathrm{Mg}_{2}$ & $22^{\mathrm{et}}$ & $25^{\mathrm{hi}}$ & $27^{j k}$ & $20 \mathrm{ed}$ & $23^{f g}$ & $26^{i j}$ \\
\hline $\mathrm{N}_{2} \mathrm{Mg}_{0}$ & $19 \mathrm{bc}$ & $26^{1 j}$ & $27^{j k}$ & $18^{b}$ & $23^{\mathrm{fg}}$ & $25^{\mathrm{hi}}$ \\
\hline $\mathrm{Mg}_{1}$ & $18^{b}$ & $25^{\mathrm{hi}}$ & $27 \mathrm{Jk}$ & $15^{\mathrm{a}}$ & $22 \mathrm{ef}$ & $24^{\mathrm{gh}}$ \\
\hline $\mathrm{Mg}_{2}$ & $20^{\mathrm{ed}}$ & $25^{\mathrm{hi}}$ & $28^{\mathrm{k} 1}$ & $16^{a}$ & 21 be & $24 \mathrm{gh}$ \\
\hline \multicolumn{7}{|c|}{$2 n d$ yaar } \\
\hline $\mathrm{N}_{1} \mathrm{Mg}_{0}$ & $22^{\mathrm{bc}}$ & $23 \mathrm{ed}$ & $27 \mathrm{et}$ & $20^{\mathrm{b}}$ & $24^{\mathrm{ed}}$ & $26^{d e}$ \\
\hline $\mathrm{Mg}_{1}$ & $24^{\mathrm{ed}}$ & $25^{\text {de }}$ & $26^{\text {de }}$ & $23^{\text {ed }}$ & $24^{\mathrm{ed}}$ & $24^{\mathrm{ed}}$ \\
\hline $\mathrm{Mg}_{2}$ & $24^{\mathrm{ed}}$ & $25^{\text {de }}$ & $26^{\text {de }}$ & $23^{\mathrm{ed}}$ & $24^{\mathrm{ed}}$ & $25^{d e}$ \\
\hline $\mathrm{N}_{2} \mathrm{Mg}_{0}$ & 22 be & $21^{\text {be }}$ & $13^{a}$ & $16^{\mathrm{a}}$ & $15^{\mathrm{a}}$ & $15^{\mathrm{a}}$ \\
\hline $\mathrm{Mg}_{1}$ & $22^{\mathrm{bc}}$ & $27 \mathrm{ef}$ & $29^{e}$ & $19^{b}$ & $24^{\mathrm{ed}}$ & $28^{\mathrm{et}}$ \\
\hline $\mathrm{Mg}_{2}$ & $19^{b}$ & $28 \mathrm{et}$ & $28 \mathrm{et}$ & $19^{b}$ & $23^{\mathrm{ed}}$ & $28^{e t}$ \\
\hline \multicolumn{7}{|l|}{$3 r d$ year } \\
\hline $\mathrm{N}_{1} \mathrm{Mg}_{0}$ & $17 \mathrm{be}$ & $20 \mathrm{ed}$ & $16^{\mathrm{ab}}$ & $13^{\mathrm{a}}$ & - & - \\
\hline $\mathrm{Mg}_{1}$ & $23^{\text {de }}$ & $23^{\text {de }}$ & $21^{d}$ & $20^{e d}$ & $22^{\text {de }}$ & $25^{e}$ \\
\hline $\mathrm{Mg}_{2}$ & $20^{\mathrm{ed}}$ & $23^{\text {de }}$ & $17^{\mathrm{be}}$ & $21^{d}$ & $21^{4}$ & $24^{e}$ \\
\hline
\end{tabular}

Meaning of index letters same as in Table 2. 
Table 5. Exchangeable cations and conductivity value in the growth base at the end of the second year $\left(\mathrm{N}_{2}\right.$ level).

\begin{tabular}{|c|c|c|c|c|c|c|}
\hline & \multicolumn{3}{|c|}{$\mathrm{Ca}_{1}$} & \multicolumn{3}{|c|}{$\mathrm{Ca}_{3}$} \\
\hline & $\mathrm{K}_{1}$ & $\mathrm{~K}_{2}$ & $\mathrm{~K}_{4}$ & $K_{1}$ & $\mathrm{~K}_{2}$ & $K_{4}$ \\
\hline \multicolumn{7}{|c|}{$\mathrm{Mg} \mathrm{mg} / 100 \mathrm{~g}$} \\
\hline $\mathrm{N}_{2} \mathrm{Mg}_{0}$ & $16^{\mathrm{ab}}$ & $16^{\mathrm{ab}}$ & $15^{\mathrm{ab}}$ & $11^{a}$ & $10^{\mathrm{a}}$ & $10^{\mathrm{a}}$ \\
\hline $\mathrm{Mg}_{1}$ & $100^{\mathrm{e}}$ & $68^{d}$ & $72^{d}$ & $69^{d}$ & $36^{\mathrm{c}}$ & $24^{\mathrm{bc}}$ \\
\hline $\mathrm{Mg}_{2}$ & $194^{\mathrm{h}}$ & $160 \mathrm{~g}$ & $169^{g}$ & $171 \mathrm{~g}$ & $139^{f}$ & $106^{e}$ \\
\hline \multicolumn{7}{|c|}{$\mathrm{Ca} \mathrm{mg} / 100 \mathrm{~g}$} \\
\hline $\mathrm{N}_{2} \mathrm{Mg}_{0}$ & $908^{a}$ & $940^{\mathrm{a}}$ & $910^{\mathrm{a}}$ & $2100^{\mathrm{b}}$ & $2172^{b}$ & $2253^{b}$ \\
\hline $\mathrm{Mg}_{1}$ & $824^{a}$ & $819^{a}$ & $816^{a}$ & $2205^{b}$ & $2220^{b}$ & $2205^{b}$ \\
\hline $\mathrm{Mg}_{2}$ & $809^{a}$ & $809^{a}$ & $830^{\mathrm{a}}$ & $2217^{b}$ & $2097^{b}$ & $2172^{b}$ \\
\hline \multicolumn{7}{|c|}{$\mathrm{K} \mathrm{mg/100} \mathrm{g}$} \\
\hline $\mathrm{N}_{2} \mathrm{Mg}_{0}$ & $42^{\mathrm{a}}$ & $68^{\mathrm{a}}$ & $306^{\mathrm{e}}$ & $47^{\mathrm{a}}$ & $84^{\mathrm{a}}$ & $222^{b}$ \\
\hline $\mathrm{Mg}_{1}$ & $42^{\mathrm{a}}$ & $66^{a}$ & $171^{b}$ & $33^{a}$ & $50^{\mathrm{a}}$ & $66^{a}$ \\
\hline $\mathrm{Mg}_{2}$ & $43^{a}$ & $62^{a}$ & $200^{b}$ & $33^{a}$ & $53^{\mathrm{a}}$ & $77^{a}$ \\
\hline \multicolumn{7}{|c|}{ Conductivity $10 \times \mathrm{mmho} / \mathrm{cm}$} \\
\hline $\mathrm{N}_{2} \mathrm{Mg}_{0}$ & $1.7 \mathrm{a}$ & $3.0^{\mathrm{abe}}$ & $7.4 \mathrm{gh}$ & $2.6^{\mathrm{ab}}$ & $6.7^{\mathrm{fgh}}$ & $7.6^{\mathrm{h}}$ \\
\hline $\mathrm{Mg}_{1}$ & $2.9^{\mathrm{abe}}$ & $3.2^{\text {abed }}$ & $5.7 \mathrm{efgh}$ & $2.9 \mathrm{abe}$ & $3.0^{\mathrm{ae}}$ & $5.6 \mathrm{efg}$ \\
\hline \multirow[t]{2}{*}{$\mathrm{Mg}_{2}$} & $4.7^{\text {ede }}$ & $5.4^{\mathrm{e} f}$ & $7.6^{\mathrm{h}}$ & $4.4^{\text {bebe }}$ & $5.1^{\text {def }}$ & $7.0^{f g h}$ \\
\hline & & & $\mathrm{K} / \mathrm{Mg}$ & & & \\
\hline $\mathrm{N}_{2} \mathrm{Mg}_{0}$ & 0.81 & 1.32 & 6.37 & 1.33 & 2.62 & 6.93 \\
\hline $\mathrm{Mg}_{1}$ & 0.13 & 0.30 & 0.74 & 0.15 & 0.43 & 0.86 \\
\hline $\mathrm{Mg}_{2}$ & 0.07 & 0.12 & 0.37 & 0.06 & 0.09 & 0.23 \\
\hline
\end{tabular}

Meaning of index letters same as in Table 2.

6). The peat, which served as the growth base, contained exchangeable magnesium $50 \mathrm{mg} / 100 \mathrm{~g}$ air-dry peat. At the end of the experiment the exchangeable magnesium content of the peat had, without magnesium fertilization, dropped as low as to $8 \mathrm{mg} / 100 \mathrm{~g}$. The annually supplied magnesium fertilization of $200 \mathrm{mg} /$ pot was not sufficient, in conjunction with the strong liming, to maintain the magnesium content of the growtb base at the original level if there had been a simultaneous strong nitrogen fertilization. The differences in the magnesium contents of the peat at the two nitrogen fertilization levels were in part caused by the annual magnesium fertilization.

The liming clearly increased the exchangeable calcium content of the peat, but the other test variables did not affect it.

The greatest potassium amount, supplied annually, has increased the exchangeable potassium content of the growth base significantly in comparation with other potassium treatments, in low limed pots at all the magnesium levels, but in the strongly limed cases only without magnesium fertilization. The great excess of exchangeable potassium in ratio to exchangeable magnesium $(\mathrm{K} / \mathrm{Mg})$ in the pots that had received no magnesium fertilization, but the greatest potassium rate, probably is one reason for the reduction in the 
Table 6. Exchangeable cations and conductivity value in the growth base at the end of the third year $\left(\mathrm{N}_{1}\right.$ level).

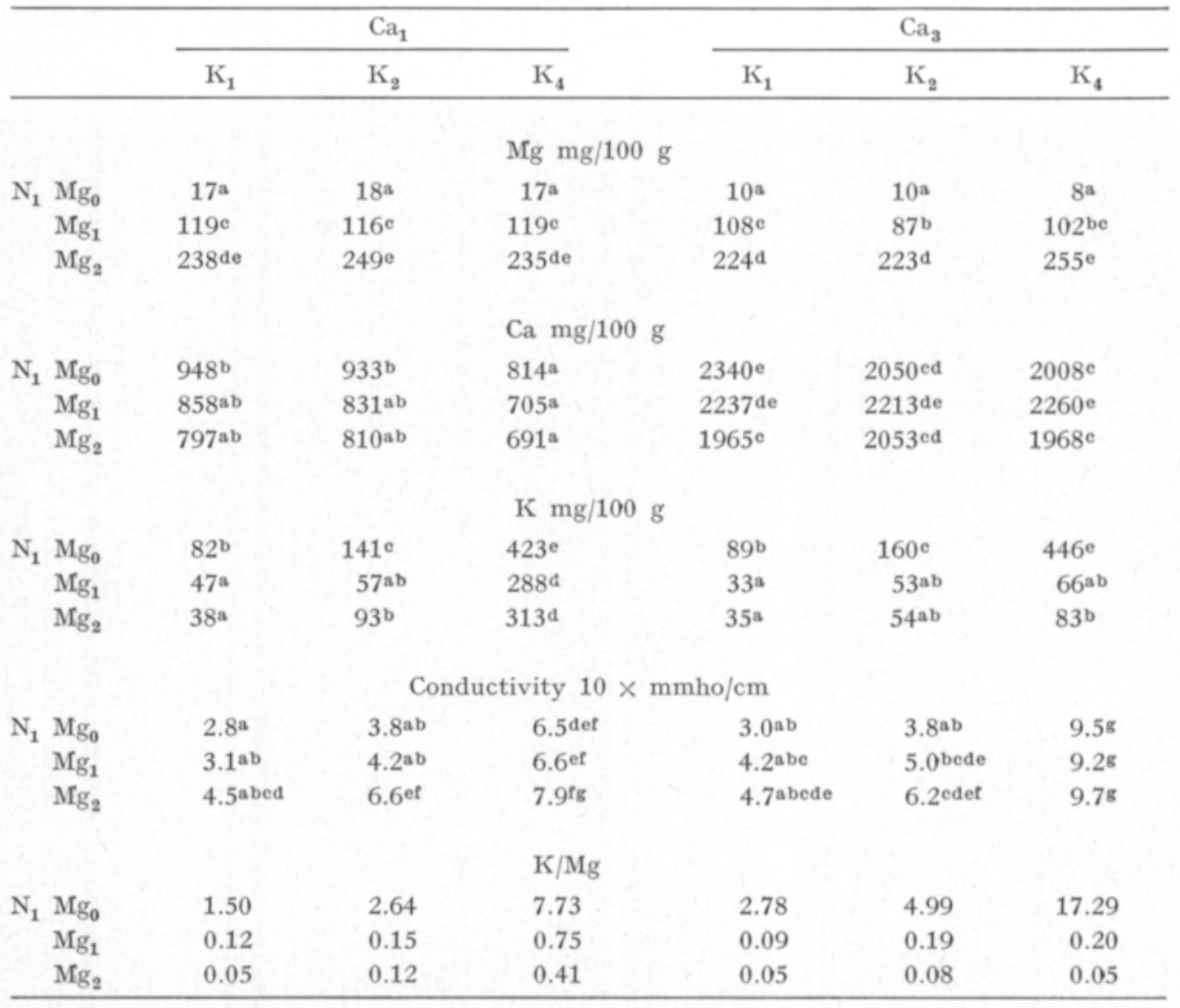

Meaning of index letters same as in Table 2.

yield. The lowest potassium rate was quite deficient, since the plants had used up some of the potassium reserves of the peat itself.

The magnesium and potassium fertilizations, given as sulphates, increased together, and separately, the concentration of water soluble salts (the conductivity value) in the growth base. The high conductivity values were, perhaps, partially responsible for the decrease in the yield in the pots that had received the abundant magnesium and potassium fertilizations.

\section{Discussion}

The magnesium reserves in the peat (exchangeable magnesium $50 \mathrm{mg} / 100$ g) were sufficient in the first year for the production of an ample grain and straw yield. The positive effect of the magnesium fertilization on the yields of the following years in this experiment is probably principally caused by the depletion of the magnesium reserves of the growth base. Without a magnesium fertilization there remained in the peat after the experiment on an average exchangeable magnesium $13 \mathrm{mg} / 100 \mathrm{~g}$. Augmenting the potassium and the nitrogen fertilizations or the liming, without magnesium, did 
not affect the yield. In a pot experiment on peat, of 5 years' duration, carried out in Norway (Sorteberg 1974), magnesium fertilization (125, 250 and $500 \mathrm{mg} \mathrm{Mg} / 5 \mathrm{1}$ ) did not affect the yield of oats. In the investigation it is mentioned that the peat contained little magnesium. In spite of that the plants grew well without magnesium fertilization. However, the magnesium content of the growth base was possibly greater than in the present investigation.

The slight reduction in the grain and the straw yields caused by the high magnesium rate, $400 \mathrm{mg} /$ pot $\mathrm{Mg}$, probably indicates that an excessive magnesium sulphate fertilization on an acid soil may impede the growth of plants (SChreiber 1950, Keränen and Jokinen 1964, JerLström 1975). The yield decreased most clearly in pots that had received the high annual amounts of magnesium and potassium sulphate. At the end of the experiment the conductivity values of their growth bases were high, and this may have impeded the growth of oats at least to some extent.

In a magnesıum deficiency situation a magnesium fertilization appeared to increase the grain yield more clearly than the straw yield. Results that point in the same direction have also been obtained on mineral soils (LEHNE and KoEPKE 1962, JeRLSTRöm 1975). The magnesium fertilization increased the weight of the grain (Wienmann 1967) and promoted the development of the grain yield. A magnesium deficiency causes growth delay (JERLSTRöm 1975), with the consequence that the grain fraction in the total yield diminishes, and the maturing of the crop is delayed (Scharrer and Mengel 1959, KERÄNEN and JOKINEN 1964).

In pot experiments carried out on mineral soil (JERLSTRÖM 1975) and on peat (SORTEBERG 1974), as well as in solution-culture experiments (OMAR and El Kobbia 1966, Falade 1973), it has been observed, corroborating the results of the present pot experiment, that the yields of various plants increase upon increasing the amount of potassium, if a sufficient amount of the other nutrients is present. In the solution experiments only saturations of potassium exceeding 48 me/l impeded growth. In the present investigation the annually supplied $1660 \mathrm{mg} /$ pot K (8.5 me/l of peat) did not depress significantly the grain and the straw yields of oats before the third year, when such a depression occured.

In the first year, when there was a sufficient concentration of exchangeable magnesium and little potassium in the growth base, the effect of the magnesium fertilization on the yields did not depend on the potassium fertilization rate. In the second and the third years the magnesium fertilization increased the grain and straw yields the more the larger the potassium fertilization that had been supplied. An increase in the ratio of the annually supplied potassium and magnesium fertilizations increased the yields of oats. In a Polish pot experiment on a lowpotassium mineral soil, a magnesium fertilization increased the yield of spring wheat only when also potassium fertilizer was used abundantly (MERCIK et al. 1976). In solution-culture experiments (BENKo and FECENKo 1970) the yield of barley shoots did not decrease unless there was a great excess of either potassium or magnesium $(\mathrm{K} / \mathrm{Mg} 59: 1$ or $1: 59)$ in the solution. 
Liming promoted the growth of the roots of plants. However, the weights of the roots were not determined in this experiment. It was observed that the straw yield increased as a result of tripling the liming rate. At the same time the grain fraction in the total crop yield diminished. The yield of corn cut at the vegetative stage increased upon the adding of more calcium, both in solution-culture (FALADE 1973) and in pot experiments (HALL and HEGwoop 1975). A high level of lime supply increased the yield of oats, and the uptake of magnesium by the yields, in every year (JokINEN 1977). For that reason, with insufficient magnesium in the third year adding more lime depressed the straw yield.

\section{REFERENCES}

Benko, V. \& Fecenko, J. 1970. Effect of various K: Mg ratios upon the formation of dry matter and the uptake of nutrients by spring barley. Acta Fytotechnica 21: 91-104.

FALADE, J. A. 1973. Interrelationships between potassium, calcium and magnesium nutrition of Zea mays L. Ann. Bot. 37: 345-353.

Hall, C. T. \& Hegwood, D. A. 1975. Effect of soil calcium level in four soil pH-magnesium combinations on the calcium and magnecium level in sweet corn (Zea mays L.). Commun. Soil Sci. Plant Anal. 6: 555-570. (Ref. Fert. Abstr. 8: 310).

HANSEN, E. M. 1972. Studies on the chemical composition of isolated soil solution and the cation absorption by plants. I. Relationship between form and amount of added nitrogen and absorption on N, K, Na, Ca and Mg by barley. Plant Soil 37: 589-607.

JERLström, H.-G. 1975. Studier över möjligheterna att med växt- och jordanalyser beskriva magnesiumsituationen i svensk växtodling. Summary: Studies on the magnesium situation in Swedish agriculture using soil and plant analysis. Inst. markvetenskap Avd. växtnäringslära Lantbrukshögskolan Uppsala. Diss. 197 p.

JoKINEN, R. 1977. Effect of added magnesium, potassium, lime and nitrogen on oats. II. Nutrient contents, cation ratios and magnesium uptake. J. Scient. Agric. Soc. Finl. 00: 49: $296-314$.

KerÄnen, T. \& JoKINEN, R. 1964. Magnesiumin puutteen torjuminen magnesiumpitoisuudeltaan erilaisilla kalkkikivijauheilla. Referat: Bekämpfung von Magnesiummangel mit Kalksteinmehlen veschiedenen Magnesiumgehalts. Ann. Agric. Fenn. 3: 244-255.

Lehne, I. \& Koepke, V. 1962. Die Wirkung einer Magnesiumdüngung magnesiumarmer Sandböden in Abhängigkeit von Kalk- und Kaligaben. Albrecht-Thaer-Archiv 6: 194-207.

McLean, E. O. \& CARbonell, M. D. 1972. Calcium, magnesium and potassium saturation ratios in two soils and their effect upon yield and nutrient content of german millet and alfalfa. Soil Sci. Soc. Amer. Proc. 36: 927-930.

Mercik, S., Goralski, J. \& Gozlinski, H. 1976. Wplyw wspoldzialania potasu z magnezem oraz potasu z sodem na plonowanie i sklad chemiczny kilku roślin. Summary: Effect of potassium-magnesium and potassium-sodium interaction on yield and chemical composition of several crops. Polish Agric. Ann. 101, 3: 103-122. Serie A.

Omar, M. A. \& El KobBia, T. 1966. Some observations on the interrelationships of potassium and magnesium. Soil Sci. 101: 437-440.

PUUSTJÄRvi, V. 1968. Cation exchange capacity in Sphagnum mosses and its effect on nutrient and water absorption. Peat Plant News 1: 54-58.

- -1971 . The activities of calcium and potassium on water and peat cultures. Acta Agr. Fenn. 123: $70-73$.

Scharrer, K. \& Mengel, K. 1958. Uber den Kalium-Magnesium-Antagonismus bei Mais und Sonnenblumen. Z. Pflanzenern. Düng. Bodenk. 83: 149-162.

Schreiber, R. 1950. Über die Wirkung des Magnesiums auf den Ertrag und die Nährstoffaufnahme von $\mathrm{K}_{2} \mathrm{O}$ und $\mathrm{MgO}$ bei den Getreidearten. Z. Pflanzenern. Düng. 48: 37-64. 
SorteberG, A. 1974. Virkningen av magnesium på avlingsstørrelse og magnesiuminnhold ved olike kalking og olike nitrogenforbindelser. Summary: The effect of magnesium application on yield and magnesium content as influenced by liming and different nitrogen sources. Forkn. Forsøk Landbr. 25: 537-558.

Steel, R. G. D. \& Torrie, J. H. 1960. Principles and procedures of statistics. New York, Toronto, London $481 \mathrm{p}$.

Wiemann, H. 1967. Die Wirkung von Mangan, Bor und Magnesium auf Weizen besonderer Berücksichtigung der Kornproteine und der Stickstoffspätdüngung. Agrikulturchem. Inst. Rheinischen Friedrich-Wilhelms Univ. Bonn. Diss. 122 p.

Ms received November 9, 1977.

\section{SELOSTUS}

\section{Magnesium-, kalium- ja typpilannoituksen sekä kalkituksen vaikutus I. Kauran satoon}

RAILI JOKINEN

Maatalouden tutkimuskeskus, Maanviljelyskemian ja -fysiikan laitos, 01300 Vantaa 30

Rahkaturve kasvualustana tutkittiin astioissa (5 1) kolmen magnesium- $\left(\mathrm{Mg}_{0}=0, \mathrm{Mg}_{1}=\right.$ 200 ja $\mathrm{Mg}_{2}=400 \mathrm{mg} /$ ast $\left.\mathrm{Mg}\right)$, kolmen kalium- $\left(\mathrm{K}_{1}=415, \mathrm{~K}_{2}=830\right.$ ja $\mathrm{K}_{4}=1660 \mathrm{mg} /$ ast $\left.\mathrm{K}\right)$, kahden kalkki- $\left(\mathrm{Ca}_{1}=2400\right.$ ja $\mathrm{Ca}_{3}=7200 \mathrm{mg} /$ ast $\left.\mathrm{Ca}\right)$ ja kahden typpimäärän $\left(\mathrm{N}_{1}=1000\right.$ ja $\mathrm{N}_{2}=2000 \mathrm{mg} /$ ast $\mathrm{N}$ ) eri yhdistelmien vaikutusta kauran jyvä- ja olkisatoon.

Kolme vuotta jatkuneessa kokeessa magnesiumlannoitus ei ensimmäisenä vuonna vaikuttanut jyvä- ja olkisatoon, jyvän kokoon ja sadon tuleentumiseen, koska kasvualustan sisältämä vaihtuvan magnesiumin määrä $(50 \mathrm{mg} / 100 \mathrm{~g}$ ilmakuivaa turvetta) oli riittävä. Magnesium varojen loputtua $200 \mathrm{mg} /$ ast $\mathrm{Mg}$ vuosittaisena lannoituksena riitti runsaan sadon muodostumiseen. Suurin kaliummäärä yhdessä kaksinkertaisen magnesiumlannoituksen kanssa aiheutti lievän sadon alenemisen, sillä veteen liukenevien suolojen määrä nousi kasvualustassa korkeaksi. Magnesiumin puute vaikeutti voimakkaammin jyvä- kuin olkisadon muodostumista, sadon tuleentuminen viivästyi ja jyvät olivat pieniä. Kaliumin ja magnesiumin suhde vuosittain uusitussa lannoituksessa, kun kumpaakin ravinnetta käytettiin, ei vaikuttanut kauran satoon. Ravinteiden määrällä oli tärkeämpi merkitys kuin ravinteiden suhteella. Kalium-, kalkki- tai typpimäärän lisäykset pienensivät kukin satoja, jos kasvit kärsivät magnesiumin puutetta. Yhdessä magnesiumin kanssa nämä käsittelyt lisäsivät sekä jyvä- että olkisatoa. Ilman magnesiumlannoitusta suurin kaliummäärä kohotti selvästi vaihtuvan kaliumin ja magnesiumin suhdetta (K/Mg) kasvualustassa ja aiheutti sadon alenemisen. 